Politics in Central Europe

(ISSN: 1801-3422)

Vol. 11, No. 2

DOI: $10.1515 /$ pce-2015-0012

\section{Attitudes towards the Government's Remembrance \\ Policy in Poland: \\ Results of an Experimental \\ Study}

\author{
PATRYK WAWRZYŃSKI \\ AND RALPH SCHATTKOWSKY
}

\begin{abstract}
The paper presents the results of an experimental study of Polish students' attitudes towards their government's remembrance policy (or, in other words, the intentional narration and interpretation of the past by the government). It includes four parts: a justification of why remembrance is a significant political asset in post-Communist Poland; a classification of remembrance policy instruments; a presentation of general results of the study; and a discussion of participants' attitudes to particular policy instruments. In our assessment of the general results, we discuss three types of collected data: the results of the initial measurement of attitudes; the results of measurement after the manipulation of emotions (neutral vs. positive vs. negative) and commitment (no commitment vs. low commitment); and the results in terms of attitude change. In the section on attitudes to particular instruments, we compare participants' support for different commemorative actions with their support for the governments' dominant role in the popularising of remembrance narratives. The study's results lead us to formulate three conclusions about the relationships between attitudes to the policy and Polish political culture.
\end{abstract}

Keywords: political attitudes, government remembrance policy, politics of memory, political culture, politics in Poland, experimental political science.

1 The paper is the result of the project Commitment, Positive vs. Negative Emotions and the Efficacy of the Politics of Memory supported by the National Science Centre in Kraków (Poland) under decision no. DEC-2013/09/N/HS5/03103.

2 We would like to express our gratitude for Mr. Marek A. Muszyński (Jagiellonian University in Kraków, Poland) and Ms. Gabriela Czarnek (Jagiellonian University in Kraków, Poland) who participated as members of the research team in the study that enabled us to gain results presented in the study. We would also like to thank prof. Dariusz Doliński (SWPS University in Wroctaw, Poland) for a support in designing the project and Ms. Beata Bielska (Nicolaus Copernicus University in Toruń, Poland) for help in organization of experiments. 


\section{Introduction}

Political leaders and governments often use interpretations of national history as a way to legitimise or substantiate their ideologies and agendas (Eyal 2004: 7, Gagiano 2004: 812, MacGinty 2001: 11). Today, political conflicts not only shape the imagination of the future, but they also fundamentally influence representations of the past; remembrance narratives have become a powerful means of political mobilisation and citizen manipulation (Khalili 2007: 222, Wawrzyński et al. 2015: 21, Weston 2008: 41-49). However, in a democracy, the government is not the only narrator of the past. It negotiates shared interpretations of national history with other significant participants in the politics of memory: minorities, local communities, non-governmental organisations, artists, academic historians and the private mass media (Fogu - Kansteiner 2006). Therefore, the issue of citizens' support for their government's role as the leading narrator of past experiences can be applied to investigate political culture (Almond, Verba 1965, Lijphart 1999).

The relationship between official narratives and the political culture is noticeable in the case of contemporary post-Communist Poland. Since the opening of the Warsaw Uprising Museum in 2004, the conservative move to endorse government as the leading narrator of national history has divided Polish society; the question of whether to support these changes has been presented as an ideological choice between conservative and liberal visions of the state (Magierska 2008: 9-27; Korzeniewski 2007: 8-10; Wolff-Powęska 2007: 39-40; Wawrzyński 2012: 68-78). Therefore in the 21st century, the government's policy on remembrance (or, in other words, its intentional narration and interpretation of past events in order to influence citizens' identities or behaviours) has become one of the key issues in political disputes in Poland and its implementation has been the subject of an emotional debate (Wolff-Powęska 2007: 3).

Polish historian Paweł Machcewicz (2012: 172-176) emphasises that attitudes towards remembrance narratives have divided society into two antagonistic groups: advocates for and critics of post-Communist Poland and its accomplishments. The core issue in this conflict is not whether government should influence shared representations of the past, but which objectives should be realised by this policy. In public debates on the procedures adopted for transitional justice, the political role of the Institute of National Remembrance and the significance of history in school curricula have been clearly evident. However, this division within Polish society has deeper causes; it is the result of different understandings of post-authoritarian trauma (Dudek 2011: 36-39, Król 2008: 24-25) and conflicting interpretations of Polish-Jewish relations during the Second World War. The latter have been radicalised since the publication of the book Neighbors by American historian Jan Tomasz Gross in 2000 (Korzeniewski 2010: 182; Machcewicz 2012: 15-16). 
Opposing assessments of the accomplishments of democratic Poland, different understandings of the authoritarian experience and conflicting representations of Polish martyrdom are not the only explanations for the increasingly politicised remembrance of Polish politics. Antoni Dudek (2011: 13) notes that history-based arguments became highly effective tools in the political contest when transitional objectives were achieved and Poland entered the European Union. Roman Kuźniar (2012: 289-290) considers the role of international challenges and the introduction of new policies on remembrance in Germany and Russia. At the same time, Zdzisław Krasnodębski (2008: 17-21) discusses the impact of the unresolved ideological dispute between the successors of inter-war Poland and descendents of Communist Poland's architects and notes that this conflict has caused the emergence of two antagonistic visions of the past, present and future.

In fact, all six factors have influenced the Polish debate on the social, cultural and political roles of remembrance narratives. However, we assume that political elites have used these symbolic triggers to exploit national history as a field of debate for two essential issues for Polish democracy: the post-transition vision of the nation's future and the limitation of governmental power. In both cases, a question about interpretations of the past has concealed a question about the relationship between the government and civil society. Thus, citizens' attitudes towards the government's remembrance policy - treated as a coherent cluster (Jackman, Miller 1996: 634) - may be considered a valuable source of knowledge about Polish political culture (Ponczek 2007: 118). Moreover, as Thomas Eckes and Bernd Six (1994) have shown, attitudes towards social and political activities correlate closely with respondents' behaviour, which makes this cluster even more interesting for political scientists.

This article considers citizens' attitudes to the government's remembrance policy in Poland with reference to a comprehensive classification of policy instruments (Wawrzyński 2014; Khalili 2007; Rydel 2011). The additional criterion enables us to compare respondents' support for the government's influence across eight rather different areas of remembrance policy. Moreover, in this experimental study, we also manipulate two dependent variables, emotional arousal (neutral vs. positive vs. negative) and incitement of commitment (no commitment vs. low commitment), to measure how different conditions may influence attitudinal change. Thus, this article is not only a presentation of empirical evaluations, but a contribution to theoretical considerations about the role of the government as a narrator of national history and the limits on its use of remembrance narratives to influence citizens in a democracy (Koczanowicz 1997: 259-260; Smith 2003: 56-59). 


\section{Instruments of Governmental Remembrance Policy}

A review of existing academic literature on the government's role as a narrator of the past leads us to create a draft taxonomy of instruments that can be used to implement a remembrance policy. ${ }^{3}$ We distinguish nine types: (1) public and civic education, (2) organisation of time, (3) use of the mass media and the fine arts, (4) topography of memory, (5) academic research, (6) specialist institutions, (7) transitional justice, (8) definitions of attitudes or values and (9) a polyphony of narratives. The first four categories are recognisable as traditional ways of enforcing governmental interpretations of the past. The next three are a result of the professionalisation of remembrance policy while the last two classes perform a modal role within the structure and so connect the other applied instruments into one composite of narratives.

\section{Figure 1: Relationships and interdependencies among instruments in the government's remembrance policy}

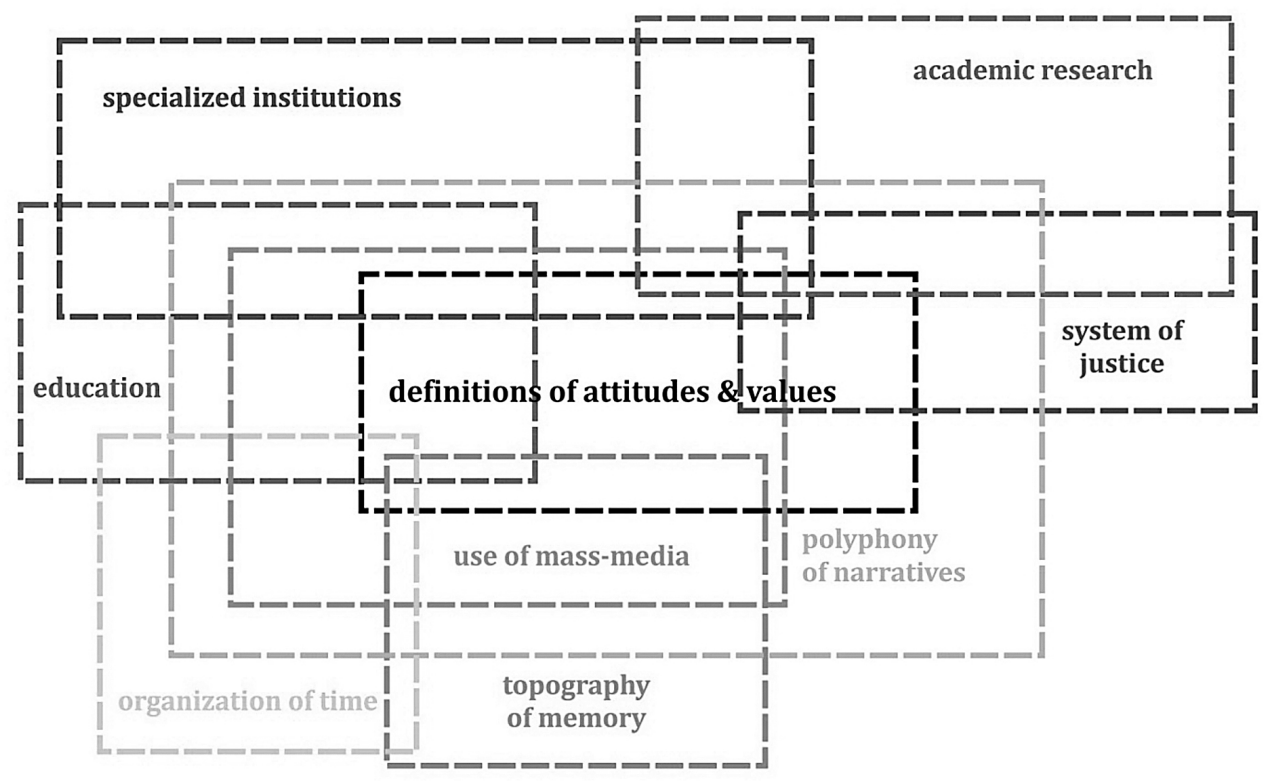

Source: Authors' own diagram

Despite the differences among them, all instruments in the government's remembrance policy are interdependent and they complement one another in a story-telling process (Assmann 1995). Figure 1 presents these relationships

3 Carried out between 2011 and 2014, this review included almost 700 items - books, papers and conference presentations - published in different countries in six languages. 
and the links between the individual categories. It also emphasises the central (or focal) role of the definitions of attitudes or values that are promoted in the narratives; we recognise this promotion as the basic objective of the government's remembrance policy. Moreover, the model shows the dominant role of the mass media in popularising narratives and interpretations and the possibility of the interactive modeling of a message (or even the mediatization of policy). These factors may be interpreted as another limit on the government's power as a narrator (Mazzoleni - Schultz 1999; Hjarvard 2008).

In Europe, the public education system has been a popular means by which governments have exerted influence since the 19th century. This system has been used to shape citizens' identities, behaviours, beliefs, opinions and knowledge through the manipulation of curricula and certain specialist civil servants - that is, schoolteachers. Currently, in well-developed countries, we can observe that public education is becoming less influential. Nevertheless, various case studies show that it can still serve as an effective instrument in the government's remembrance policy: it is used to establish emotional relationships between citizens and the interpretation of the past (Dror 2001); to promote a selection of events which are significant for national identity (Yablonka 2009); to associate past experiences with preferred behaviours (Meseth - Proske 2010); to shape political preferences (Bukh 2008; Fukuoka 2011) and even to mobilise young citizens and involve them as an additional force in ongoing political conflicts (Wang 2008). ${ }^{4}$

The organisation of time results in an official calendar of political holidays and it informs citizens about the past events which are to be commemorated or celebrated. This instrument is not, however, limited to the creation of holidays, celebrations of anniversaries or the constitution of an official calendar of remembrance. Rather, as David Cesarani (2001: 40-43) and Neil Gregor (2001: 71-78) note, its effectiveness is based on the establishment of political links between commemorated events and contemporary identities or patterns of behaviours. Thus, the organisation of time has two main dimensions: the selection of past experiences and the interpretation of their significance for the present (Grundlingh 2004: 361). ${ }^{5}$

4 In the case of Poland, this shift cannot be observed, and public education is still being used by the government in a rather traditional way: to popularise unambiguous interpretations of national history during (at least) five hundred hours of compulsory lessons of history and civic education (Smoczyńska et al. 2012).

5 In Poland, the official calendar of political holidays includes two national holidays that are non-working days - Constitution Day (03 May) and Independence Day (11 November). In addition, there are three national holidays that are working days - "Cursed Soldiers"' Remembrance Day (01 March), Warsaw Uprising Remembrance Day (01 August) and Solidarity and Freedom Day (31 August) - and nine less significant public holidays. The Polish calendar also includes National Victory and Freedom Day (09 May), but these has not been celebrated since the fall of Communism. 
The government's remembrance policy should be seen as a method of exerting political influence, and thus, it requires the existence of reliable channels of communication between the government and citizens. While public education shapes the younger generations, the use of mass media and the fine arts enables political elites to popularise their interpretations for the entire society. The mass media format offers narratives with a high degree of emotionalism, which often has to be reduced in other instruments; in addition, it enables the government to present simplified (or mythical) interpretations and to popularise unproven hypotheses about the past, an option that is also limited for other instruments (Baer 2001; Kansteiner 2004; Landsberg 1997; Lisus - Ericson 1995; Meyen Pfaff-Rüdiger 2014). Moreover, Olaf Hoerschelmann (2001) and Katja Fullard (2010) point out that mass media and the fine arts may be used by governments to introduce new remembrance issues into the public debate or to accustom citizens to new interpretations of national history.

Like the organisation of time, a topography of memory seems to have been applied since the very beginning of political organisation (Assmann 1995). This aspect of a remembrance policy symbolically represents the government's power over the landscape. It includes two main strategies: the establishing or creation of new landmarks (e.g. monuments, graveyards, public buildings) and the naming of places, both natural (e.g. mountains, rivers, islands) and created by humankind (e.g. streets, parks, cities, schools, libraries). Owen J. Dwyer and Derek H. Alderman (2008) consider three different aspects of the alliance between remembrance and space: (1) space as the content of narrative, (2) space as an arena for competing narratives and (3) space as the stage for commemorative rituals. The last aspect leads to the sanctification of places and the delimitation of areas where past events manifest themselves in the present (Carlson 2006; Eschebach 2011; Gotham - Greenberg 2008; Schaller 2007; Schramm 2011).

The professionalisation of the government's remembrance policy results in a closer relationship between political authorities and the academic community. Although the nature of scientific investigations (to some extent) limits the utility of academic research as an instrument of social influence (Friedländer 2000: 13-14; Tamm 2014), at least three reasons may lead to the involvement of social scientists in the government's story-telling: (1) ideological or conditional (reward vs. punishment) motivations, (2) the desire to investigate research problems which seem to be popular or significant and (3) adaptation to a grant system which favours certain types of studies and some research topics. In all three cases, scientists' involvement may be unconscious, unintentional or involuntary, but in non-democratic countries, the academic community may also participate in the government's premeditated manipulation of society (Mitter 2003; Shafir 2014; Uldricks 2009). ${ }^{6}$

6 In the case of Poland, it is worth mentioning that a public institution, the Institute of National Remembrance is the leading centre for studies of contemporary history; its researchers have their own system 
The development of specialist institutions is also due to the professionalisation of the government's remembrance policy. Museums, galleries, libraries, archives, institutes, centres, educational parks and commemorative chambers integrate civic education and academic research and multiply policy's influence across a society. Specialist institutions stimulate and inspire citizens and integrate them into a single community of remembrance (Wawrzyński 2014). Their role is not limited to the narrating of past events: they explain national history (Landsberg 1997), highlight links between the past and the present (Berman 2001; Worthy 2004), reinforce individuals' commitment to narratives (Cadot 2010; Freed 1989) and integrate remembrance narratives with essential definitions of national identity (Seo 2008). In the 21st century, however, specialist institutions have become so popular because they often offer less official communication. They are spaces of individualised and diverse interactions between the narrator and recipient which enable both sides to negotiate (equivalent) interpretations of past events (Lisus - Ericson 1995: 18).

Sometimes specialist institutions are established as part of the system of justice. As such, they popularise a simplified vision of reality in which heroes are rewarded and wrongdoers are punished by the government (Valiñas Vanspauwen 2009: 270). Especially in the transition period, use of the judiciary plays a significant role in the remembrance policy; it prevents citizens from experiencing injustice and curtails less-than-empathetic attitudes towards victims of former repressions or harms (Dalbert 2009: 288; Bègue Muller 2006). In her study of transitional justice, Lavinia Stan (2006: 383) notes that the alliance between remembrance and justice results in powerful labels and enables governments to distinguish heroes and victims from villains and tormentors. Moreover, thanks to this alliance, political elites are able to control public expressions of emotions and the political system is protected from the rank-and-file deconstruction (Elster 2004; Grosswald Curran 2003) which may be caused by unhealed political trauma (Kattago 2001: 41; Withuis 2010: 1-3; Beall 2006: 470-471; Eyal 2004).

Our classification of the instruments of the government's remembrance policy also includes two modal types of action, which connect other instruments and establish all the stories in one composite of narratives. The first of these definitions of attitudes and values - explains ideas, beliefs, convictions, patterns of behaviour, political visions and shared images by reference to interpretations of national history. It combines various aspects of policy so as to label past actions on the basis of present political standards (Schwartz - Schuman 2005; Schwartz 1996). Definitions of attitudes and values therefore determine whether

of financing investigations and it is closed to researchers from universities and other institutions. Moreover, the Polish academic community is highly dependent on the Ministry of Science and Higher Education and other governmental agencies which distribute financial support for research. 
narratives will be nationalised or privatised (Gutwein 2009); as such, this instrument also establishes a type of relationship between a government, a society and a remembrance narrative (Moyn 1998). On the other hand, the polyphony of narratives delivers social proof of the correctness of an interpretation (Cialdini 2003: 100-105). It is the reason why governments aim to use diverse narrators with different authorities (Cappalletto 2003: 241). Such persons include witnesses of past events, respected members of local communities, historians, archaeologists, school-teachers, artists, journalists, celebrities and political leaders. The plurality of story-tellers increases the presumed authenticity of the narrative and its interpretation.

\section{Methodology of the Experimental Study}

The measurement of attitudes to the government's remembrance narratives in Poland was undertaken in December 2014 and January 2015 at Nicolaus Copernicus University in Torun and its medical school in Bydgoszcz. The participants in the study were 364 male and female students (aged 18-29 years with an average age of 21 years old) with different academic majors: accountancy, biotechnology, cognitive studies, computer science, economics, education studies, journalism, international relations, management, mathematics, pharmacy, philology, security studies and social work. The selected sample was random since the recruitment procedure for the study was based on voluntary participation in the experiment. We therefore do not recognise the final results as representative of the population, but rather see them as an observation of attitudes among a select group of university students.

In the study, 364 participants were randomly assigned to six experimental conditions that were based on the project's research design. We introduced two dependent variables: the arousal of emotions (neutral vs. positive vs. negative) and the incitement of commitment (no commitment vs. low commitment). We then observed and compared attitude changes under the different experimental conditions. The manipulation of emotions was achieved based on the presentation of three short movies about the 1945 Augustów Roundup that were produced for the study; the narrators of these movies expressed neutrality, pride or sorrow. Moreover, participants were also asked to write either a short informative text about the topic of movie (the "no-commitment condition") or a short persuasive text about it (the "low-commitment condition"). In sum, they were randomly assigned to watch one of three movies and then to write one of two types of text. This procedure enabled the research team not only to measure students' attitudes towards the remembrance policy, but to observe how different uses of emotions or commitment may influence attitude changes in just half an hour.

In the study, we used a new research tool, a questionnaire about attitudes to the government's remembrance policy, which was constructed after a pre-test 
procedure with 449 participants (in Torun and Kraków). Moreover, ten experts were asked to assess the questions' relevance to the theoretical category under discussion. As a result, we created two parallel versions (A and B) of the questionnaire with 17 items each, including two reverse questions in both versions. During the experiments, participants were asked to express their support for the statements presented on a seven-level Likert scale. ${ }^{7}$ The minimum score was, thus, 17 points while the maximum score was 119 points. The total score can be used to determine seven general attitude types: strongly negative (17-32 points), negative (33-46), fairly negative (47-61), moderate (62-75), fairly positive (76-90), positive (91-105) and strongly positive (106-119).

Particular items in the questionnaire were presented as statements about specific tools in the government's remembrance policy. Public education was considered four times, the organisation of time seven times, the use of mass media and the fine arts five times, the topography of memory five times, academic research twice, specialist institutions five times, the system of justice once and definitions of attitudes and values twice. ${ }^{8}$ Moreover, three other questions discussed general aspects of the remembrance policy. The questionnaire integrated two basic and opposing (idealised) types of attitudes: (1) the government should not be a narrator of national history vs. the government should be the leading narrator of remembrance discourse and (2) narratives of past events are irrelevant to my identity and political decisions vs. remembrance narratives greatly influence my identity and political decisions. These dichotomies were concurrently investigated on three levels: cognitive, behavioural and emotional.

All experiments were carried out under the same circumstances. Firstly, participants were asked to share basic information (sex, age, academic major) and to assess their interest in history and politics. Secondly, they were asked to complete an initial version of the attitudes questionnaire (17 items) followed by the need-for-closure questionnaire and a test of their knowledge of history and remembrance. Thirdly, a movie was presented. Afterwards, participants were asked to fill out a manipulation assessment form and to answer four simple questions about the movie. Next, they were asked to write a short text about the narrative presented. This text was to be informative or persuasive depending on the assigned condition. Finally, all participants were asked to complete a second version of the attitudes questionnaire (17 items). Before retesting took place, they had, thus, experienced the manipulation of their emotional arousal (through a movie) and commitment to the narrative (through the writing of the short text).

7 In the study, we used the following format: 1 - strongly disagree, 2 - disagree, 3 - disagree somewhat, 4 - neither agree nor disagree, 5 - agree somewhat, 6 - agree, 7 - strongly agree.

8 None of the questions considered the polyphony of narratives because of the rather modal role that this has in the policy. 


\section{General Results of the Experimental Study}

The average score for the 364 participants in their first (pre-test) attempt at the attitudes questionnaire was 73.90 points, which suggests a moderate level of support among students for both the government's remembrance policy in Poland and the role of national history in social and political life. The data collected showed that the participants' attitude to the government's role as the principal narrator of past events was more positive than negative, however only two participants $(0.55 \%)$ expressed a highly positive attitude while 44 of them $(12.09 \%)$ displayed a positive attitude. Furthermore, we noted that male participants showed slightly more support than female participants for the remembrance policy ( 76.30 points versus 73.18 points). We also observed some differences across the age groups: in general, younger students had higher overall results, but the decline in support was not linear and could not be explained by the age of participants. In terms of academic majors, the most favourable attitudes were expressed by students of international relations (79.42 points) followed by those majoring in accountancy ( 77.61 points), security studies (76.98 points) and journalism (76.27 points) while students of education studies (65.39 points), mathematics and computer science (65.80 points) and management (65.93 points) were less supportive.

The results of the initial measurement of attitudes to the remembrance policy showed that citizens' support for the government as the leading narrator of past experiences was connected to their interest in history. ${ }^{9}$ Participants who were highly interested had an average score of 85.75 points. Other scores were as follows for participants with different levels of interest: interested (84.79 points); quite interested ( 80.90 points); neither interested nor uninterested (73.13 points); quite uninterested (70.26 points), uninterested (62.61 points) and highly uninterested (59.59 points). Thus, participants' curiosity regulated the extent of their support for politicised remembrance and its role in the political life of the nation. This relationship was less visible when it came to their interest in politics, however, participants with a higher declared level of interest tended to have better results in the questionnaire. The knowledge test concerning history and remembrance also revealed interesting differences: erudition was associated with greater support for the policy and on average, participants who scored six or more points (of a possible 11.0) had quite a positive attitude towards the government as the principal narrator of the past.

The results of the need-for-closure questionnaire also delivered valuable insights into the dynamics of support for the government's remembrance policy in Poland. Participants who had a preference for order endorsed the policy

9 This was also measured on a seven-level Likert scale: 1 - highly uninterested, 2 - uninterested, 3 - quite uninterested, 4 - neither interested nor uninterested, 5 - quite interested, 6 - interested, 7 - highly interested. 
more strongly (low-level preference: 71.78 points; moderate-level preference: 73.26 points; high-level preference: 75.32 points). Participants who favoured predictability also showed a greater level of support (low-level preference: 70.83 points; moderate-level preference: 74.27 points; high-level preference: 75.63 points). Furthermore, the difference in attitudes was noticeable when it came to opposition to ambiguity (low-level opposition: 59.71 points; moderate-level opposition: 73.62 points; high-level opposition: 74.54 points). There was no observable relationship between closed-mindedness or decisiveness and support for the policy and the government's role as the principal narrator of remembrance.

The experimental manipulation of emotions and commitment caused observable attitudinal changes. The average score for all the participants in the second (post-test) questionnaire was 75.82 points, an increase of $2.60 \%$; this suggested that opinions about the government's remembrance policy in Poland were generally rather positive. It is worth emphasising that this change came as a result of participants just watching a short movie and answering a simple question. Moreover, seven students (1.92\%) expressed a highly positive attitude while another $52(14.29 \%)$ manifested a positive attitude. In the second measurement, the difference between male and female participants decreased (with scores of 76.82 points for the former vs. 75.52 points for the latter); there continued to be no linear relationship between age and the average result. Turning to academic majors, the greatest support for the government as the principal narrator of past events came from students of international relations (81.18 points) followed by those majoring in pharmacy (79.68 points, $a+6 \%$ increase), cognitive studies (79.67 points, a $+5 \%$ increase), security studies (79.19 points), accountancy (78.11 points) and journalism (76.81 points). The least supportive were again students of mathematics and computer science (66.00 points) followed by those studying education studies and management (both with 69.00 points).

The results of the second measurement of attitudes confirmed the previously observed connection between support for the remembrance policy and an interest in history. It was only in the case of participants who were highly uninterested that we noted a decrease in the average score (from 59.59 to 57.91 points). For all other groups we observed a score increase; the largest of these was in the group of participants who were highly interested in history (whose scores leapt from 85.75 points to 90.00 points). The second measurement also showed, that a higher level of interest in politics was associated with stronger support for the policy. The knowledge test enabled us to detect a linear relationship between the test result and the average score in the second measurement; on average, participants who scored five or more points (out of a possible 11.0) in the test had quite a positive attitude to the government's role as the principal narrator of past experiences. 
The results of the need-for-closure questionnaire were again quite informative. In our post-manipulation measurement, we observed once more that participants with a greater preference for order were more supportive of the policy (low-level preference: 74.83 points; moderate-level preference: 75.33 points; high-level preference: 76.75 points) though the differences were less visible this time. In the case of the preference for predictability, the distinctions between the participants increased; a stronger preference for predictability led to an even greater endorsement of the policy (low-level preference: 71.68 points; moderate-level preference: 76.10 points; high-level preference: 78.79 points). Once again, the differences were also noticeable among participants with varying levels of opposition to ambiguity (low-level opposition: 58.29 points; moderate-level opposition: 76.09 points; high-level opposition: 76.21 points). In general, a lower level of closed-mindedness was connected with a more favourable attitude, and moderately decisive participants were most supportive of the remembrance policy.

The use of two parallel versions of the attitude questionnaire enabled us to observe changes in the level of support for the government as a result of exposure to a narrative. Generally, the average score increased by $2.60 \%$. However, this increase was more likely in the case of participants with a lower score in the pre-manipulation measurement. (The changes recorded by score results were as follows: very low: $6.60 \%$; low: $3.48 \%$; moderate: $2.59 \%$; high: $0.08 \%$; very high:- $0.25 \%$. ${ }^{10}$ We also observed that the change among the female group (3.20\%) was more significant than the one among the male group (0.69\%). The age of the participants did not influence any attitude changes. On the other hand, a comparison of students with various academic majors revealed interesting differences: a small increase was observed in the cases of students of mathematics and computer science $(0.30 \%)$, economics $(0.40 \%)$, accountancy $(0.64 \%)$, journalism $(0.71 \%)$, philology $(0.72 \%)$ and biotechnology $(0.80 \%)$. Some increases were also seen among students of international relations $(2.22 \%)$ and security studies $(2.87 \%)$ while there were notable increases among students of management (4.66\%), cognitive studies $(5.52 \%)$, education studies $(5.52 \%)$, social work $(6.00 \%)$ and pharmacy $(6.32 \%)$.

Only participants who were highly uninterested in history experienced a decrease in their support for the remembrance policy $(-2.82 \%)$. In contrast, the most significant increases were seen among the groups who were highly interested in history (4.96\%) or uninterested in the subject (4.58\%). Similar observations were made about participants' interest in politics: those who were highly uninterested in the field recorded a slight decrease (-0.08\%); the biggest increases occurred among the groups who were uninterested (5.91\%), quite interested $(5.31 \%)$ or highly interested $(4.34 \%)$ in the subject. These results

10 This division is based on quintiles in the first measurement. 
show that exposure to a narrative may also be an effective stimulus among citizens who are not interested in history and politics. The results of the knowledge test confirmed this observation: participants who scored fewer than two points (out of a possible 11.0) experienced a significant decrease in their support $(-10.08 \%)$ while the highest increases took place among participants with two points $(4.42 \%)$ or seven or more points $(3.72 \%)$. Our experimental study, thus, proved that the potential effectiveness of the government's remembrance policy is not limited to recipients who are interested or educated in history and politics.

Participants with less of a preference for order tended to see greater increases in their support (low-level preference: $4.25 \%$; moderate-level preference: $2.81 \%$; high-level preference: $1.90 \%$ ). In the case of the preference for predictability, the opposite relationship was observed (the increase was $1.21 \%$ for those with a low-level preference; $2.47 \%$ for a moderate-level preference and $4.7 \%$ for a high-level preference). A lower level of opposition to ambiguity caused a decline in support $(-2.38 \%)$ while moderate - and high-level opposition were related to a greater susceptibility to manipulation (with shifts of $3.36 \%$ and $2.24 \%$ respectively). A lower level of decisiveness was associated with a slightly greater attitude change (low-level decisiveness: $2.75 \%$; moderate-level decisiveness: $2.63 \%$; high-level decisiveness: $2.31 \%$ ). In the case of closed-mindedness, the reverse relationship applied (low-level close-mindedness: 2.24\%; moderate-level close-mindedness: 3.04\%). Nevertheless, less closed-minded participants continued to express more favourable attitudes to the government's remembrance policy.

As part of the study, we also observed how differences in the emotional character of a narrative can influence attitude change. Participants were randomly assigned to watch one of three short movies: the first of these presented a story without any additional attempt to arouse emotions (the neutral condition); the second also attempted to induce pride (the positive condition) and the third presented a story and made an additional effort to induce sorrow (the negative condition). After watching the emotionally neutral movie, participants experienced a $3.10 \%$ increase in their level of support for the government's policy; in the positive condition, the level of change was slightly higher (3.54\%) while in the negative condition, we observed an increase of only $1.15 \%$. The manipulation of commitment also caused different results: participants assigned to the no-commitment condition (writing a short informative text) experienced a $2.37 \%$ increase; those fulfilling the low-commitment condition (writing a short persuasive text) experienced a $3.42 \%$ increase while a reverse commitment ${ }^{11}$ led to a noticeable decrease in support $(-3.19 \%)$.

11 Nineteen participants assigned to the low-commitment condition wrote persuasive texts opposing the promotion of the presented narrative. We decided to treat these as cases of "reverse commitment." 
The most influential combination of emotions and commitment was low commitment with the additional inducement of pride (producing a change of $4.60 \%)$. The presence of positive emotions without the incitement of any commitment was less effective (3.05\%). Surprisingly, in neutral conditions, the lack of any commitment was slightly more effective (3.33\%) than a low-level commitment (3.13\% change). When sorrow was induced in addition to a low level of commitment, there was a greater increase in support $(2.49 \%)$ than was the case in the same scenario with the no-commitment condition $(0.66 \%)$. Moreover, the presence of additional emotions intensified the negative influence of the reverse commitment (neutral state: $-1.30 \%$, positive emotions: $-1.98 \%$, negative emotions: $-5.44 \%)$.

\section{Attitudes to Tools in the Government's Remembrance Policy}

The data collected were useful not only for investigating general attitudes to the government's remembrance policy in Poland, but also for considering attitudes to particular policy instruments. As has been mentioned, the two parallel versions of the questionnaire each presented 31 statements that referred to specific government actions along with another three more general statements. In the case of 18 statements, the support declared for the policy was above average while for the other 16 items, it was below average.

After the first measurement (whose results were not influenced by experimental manipulation), we noted that the support declared for all the general statements was above average. The participants tended to agree that they felt regret about the presence of unresolved issues in contemporary Polish history (for an average score of 5.62 out of a possible 7.0); they also agreed that they were not indifferent to Polish heroes of the past (for an average score of 5.16). Moreover, participants expressed a moderate level of support for the government's involvement in resolving historical issues even if this might cause conflicts with other countries (for an average score of 4.48). Notably, participants' general attitudes to the policy were rather positive and they recognised remembrance as a significant aspect of national politics and their political identities.

On the matter of public education, the participants in the study were less supportive: the results for two items showed an above-average level of support while for another two questions, the level was below average. Polish students somewhat agreed that history is one of the most significant courses at school because it educates informed citizens (for an average score of 4.73) and that during classes, pupils should learn more about the patrons of their schools ${ }^{12}$ even if this is at the expense of other courses (average score of 4.35). However,

12 Polish state schools often have a patron, an international, national or local hero who is presented as a role model for pupils. 
they neither agreed nor disagreed that the government should fund not just public education but also other ways of popularising historical knowledge regardless of the costs (average score: 4.16) and they disagreed somewhat that there should be extra history lessons instead of other courses at school (average score: 3.52 ). Therefore, Polish students did not express their support for using public education in the remembrance policy although they recognised its role in shaping civic behaviour.

The organisation of time met with rather a positive response from participants: the results of four items were above average while the other three had below-average results. Polish students agreed that political leaders should participate in celebrations of significant anniversaries (average score: 4.92); they supported the government funding of active forms of commemoration, e.g. location-based games or guided excursions (average score: 4.88); they agreed somewhat that celebrations of significant anniversaries should be ceremonial regardless of the expense (average score: 4.75 ) and they also supported the statement that the organisation of time is essential for the national community even if this is connected with the promotion of one interpretation of history (average score: 4.70). However, the participants were less supportive when questions considered their emotions and behaviour. They neither agreed nor disagreed that they felt unemotional when participating in national commemorations (average score: 4.02) or that it was important to participate in celebrations of significant anniversaries (average score: 3.90 ). Moreover, they disagreed somewhat that they preferred participating in national commemorations to taking a stroll in the park (average score: 3.71). Polish students, thus, expressed their support for the government's actions, but were fairly uninterested in participating in these events.

In the study, the lowest level of support was attached to the use of mass media in the government's remembrance policy: only one item here had an above-average result while the results of the other four were below average. Participants agreed somewhat that they watched historical films on public television with interest and attention (average score: 4.48). At the same time, Polish students neither agreed nor disagreed that reading about or listening to accounts of famous battles stimulates their imagination (average score: 3.91 ) or that public television should include more shows concerning national history (average score: 3.91 ). They also neither agreed nor disagreed that they preferred special editions of newspapers about the past over other special editions (average score: 3.84 ). Moreover, participants somewhat disagreed that they would watch news broadcasts more often if the latter focused more on history (average score: 3.48$)$. These results may lead us to form two quite different conclusions: first, we may see them as the reflection of rather negative attitudes to the use of mass media as a remembrance policy instrument. Second, we may recognise them as a consequence of the government's inability to combine remembrance 
narratives with entertainment. If we accept this second interpretation, we will also agree that Poland's remembrance policy is being implemented ineffectively since in the 21st century, the mass media seem to be the key instrument for popularising narratives.

The attitudes observed towards the topography of memory were the most supportive of the government: four results were above average while one was below average. Participants in the study agreed that monuments to Polish heroes are not irrelevant to them (average score: 4.91 ). They agreed somewhat that they experience strong emotions when visiting commemorative sites (average score: 4.57), that building monuments is important despite the possible expense (average score: 4.47) and that they feel pride when they see monuments of Polish national heroes even when those heroes are not unblemished (average score: 4.47). Only the commemoration of significant events despite possible conflicts with other countries met with a slightly less favourable response from participants (average score: 4.23). The study's results showed that Polish students considered the public space to be a stage for commemorative rituals and an arena for narratives and that they recognised the government's dominance in this sphere.

As regards academic research, participants somewhat disagreed with the idea of giving additional funding to studies of contemporary history instead of other topics (average score: 3.69). Nevertheless, they agreed that they were interested in documentary films about Polish history (average score: 4.87 ) - again, this showed that Polish students like the outcomes of the alliance of remembrance and cinematography. Concerning specialist institutions for remembrance policy, the participants expressed less approval: the result was above average for only one item and it was below average for the other four. The participants agreed that visiting historical museums is a reflective experience (average score: 4.90). At the same time, they neither agreed nor disagreed on any of the following propositions: they would like to participate in a debate organised by the Institute of National Remembrance (average score: 4.03); the government should fund institutions that specialise in the documentation of history even at the expense of other policies (average score: 3.99); the government should build new historical museums even if doing so could be a financial liability (average score: 3.80). Moreover, the participants somewhat disagreed that they would prefer to see public support for remembrance projects over support for sports infrastructure projects (average score: 3.55). These results lead us to an interesting observation: even if Polish students like experiencing remembrance narratives, they do not tend to agree with the public funding of institutions dedicated to creating and promoting these narratives.

The participants in the study expressed the opposite attitude to public funding when it came to special pensions for former underground soldiers during the Second World War which they agreed should be financed by the government (average score: 5.05). Regarding definitions of attitudes and values, they agreed 
that the lack of commemoration of past heroes is sad (average score: 4.75); they neither agreed nor disagreed that national heroes should be presented as civic role models even if the selection of examples may be controversial (average score: 4.00). Polish students, thus, clearly agreed that the commemoration of national heroes is the government's duty, but they expressed some reservations when asked to call controversial heroes role models.

\section{Conclusions}

In our experimental study, we investigated the influence of emotions and commitment on Polish students' attitudes to the government's remembrance policy. We also studied various aspects of these attitudes, especially the level of support for the government's use of particular tools for popularising narrative. Our basic research objective was to consider whether emotions and commitment can explain the effectiveness of remembrance narratives as a political asset. While undertaking the project, however, we noticed that - to some degree - we were also performing a diagnosis of the state of the relationships between remembrance, national history, the government and Polish students. This article has been a presentation of that diagnosis.

We stated earlier that citizens' attitudes to the remembrance policy may be applied to discuss Polish political culture. The overall results of the first (pre-manipulation) measurement of attitudes suggest that Polish students tended to approve somewhat of the government's dominant role in the politics of memory and they recognised remembrance as the duty of political elites rather than a task for civil society. Participants in the study supported the government's dominance in the public sphere and they legitimised its power to name places and recreate landscapes (Guyot - Seethal 2007). However, although Polish students generally recognised the significance of remembrance and its role in shaping civic behaviours, they were rather unwilling to support the development of three key policy instruments: public education, specialist institutions and the use of the mass media. The issue remains whether their stance was moderate because of the very nature of these actions or because they did not agree with the current methods of their application.

The results of the study lead us to an intriguing observation: Polish students agreed that the government should implement a remembrance policy, but they did not like being involved in these actions. They agreed therefore that there is some symbolic distinction between the duties of the political elite and the duties of the ordinary citizen. As a result, they were more interested in being the subordinated subjects of a remembrance policy than in being active participants in historical debates. However, participants saw two limitations on the government's power: first, they expected that the policy would not be used to incite political conflicts, and second, they were rather unwilling to support 
the funding of new commemorative initiatives from their taxes. We may, thus, assume that Polish students recognised remembrance as an ideology which establishes a national community, but they were rather opposed to increasing the costs of the government's management of collective memory.

The collected data enable us to formulate three conclusions: first, we may note that in the case of remembrance policy, the participants in the study were more supportive of the government than of civil society. Second, these participants preferred not to be involved in commemorative actions, which they recognised as being the domain of political elites. Third, the participants considered remembrance to be a type of ideology which the government and political elites should use to consolidate the citizenry and prevent conflicts. In addition, the study results allow us to create a general profile for the strong supporter of the government's remembrance policy: this is a citizen who is interested in history and politics, has developed knowledge of national history, prefers order and predictability, does not like ambiguity, is not closed-minded and has a fairly moderate level of decisiveness. And as another part of our experimental study showed, the more supportive participants were five times more likely to be personally involved in popularising the narrative than all of the participants. Thus, students who were more obedient to the government were also more willing to engage in political actions. This shows that in post-transitional Poland, political elites still dominate civil society on the basis of remembrance and Polish students are rather supportive of this state of affairs.

\section{References}

Almond, Gabriel A., Verba, Sidney (1965): The Civic Culture. Boston: Little, Brown and Co.

Assmann, Jan (1995): Collective Memory and Cultural Identity. "New German Critique" 68, 125-133.

Baer, Alejandro (2001): Consuming history and memory through mass media products. European Journal of Cultural Studies 4 (4): 491-501.

Beall, Jo (2006): Cultural Weapons: Traditions, Inventions and the Transition to Democratic Governance in Metropolitan Durban. Urban Studies 43 (2): 457-473.

Bègue, Laurent, Muller, Dominique (2006): Belief in a just world as a moderator of hostile attributional bias. British Journal of Social Psychology 45, 117-126.

Berman, Judith E. (2001): Holocaust Museums in Australia: The Impact of Holocaust Denial and the Role of the Survivors. Journal of Holocaust Education 10 (1): 67-88.

Bukh, Alexander (2007): Japan's History Textbooks Debate: National Identity in Narratives of Victimhood and Victimization. Asian Survey 47 (5): 683-704.

Cadot, Christine (2010): Can Museums Help Build a European Memory? The Example of the Musée de l'Europe in Brussels in the Light of 'New World' Museums' Experience. Journal of Politics, Culture and Society 23, 127-136. 
Cappalletto, Francesca (2003): Long-Term Memory of Extreme Events: From Autobiography to History. The Journal of Royal Anthropological Institute 9 (2): 241-260.

Carlson, Marla (2006): Looking, Listening, and Remembering: Ways to Walk New York after 9/11. Theatre Journal 58: 3, 395-416.

Cesarani, David (2001): Does the Singularity of Holocaust make it Incomparable and Inoperative for Commemorating, Studying and Preventing Genocide? Britain's Holocaust Memorial Day as a Case Study. Journal of Holocaust Education 10 (2): 40-56.

Cialdini, Robert B. (2003): Influence. Science and Practice. Boston: Allyn and Bacon.

Dalbert, Claudia (2009): Belief in a just world, in M.R. Leary \& R. H. Hoyle. Handbook of Individual Differences in Social Behaviour. New York: Guliford Publications, 288-297.

Dror, Yuval (2001): Holocaust Curricula in Israeli Secondary Schools, 1960s-1990s: Historical Evaluation from Moral Education Perspective. Journal of Holocaust Education 10 (2): 29-39.

Dudek, Antoni (2011): Instytut. Osobista historia IPN. Warszawa: Czerwone i Czarne.

Eckes, Thomas, SIX, Bernd (1994): Fakten und Fiktionen in der Einstellung-Verhaltens-Forschung: Eine Meta-Analyse. Zeitschrift für Sozialpsychologie 25, 253-271.

Elster, Jon (2004): Closing the books: transitional justice in historical perspective. New York: Cambridge University Press.

Eschebach, Insa (2011): Soil, Ashes, Commemoration. Process of Sacralization at the Ravensbrück Former Concentration Camp. History \& Memory 23 (1): 131-156.

EyaL, Gil (2004): Identity and Trauma. Two Forms of the Will to Memory. History \& Memory 16 (1): 5-36.

FOGU, Claudio, Kansteiner, Wolf (2006): The Politics of Memory and the Poetics of History, in R. N. Lebow, W. Kansteiner \& C. Fogu. The Politics of Memory in Postwar Europe. Durham - London: Duke Univeristy Press, 284-310.

Freed, James Ingo (1989): The United States Holocaust Memorial Museum. Assemblage 9, 58-79.

Friedländer, Saul (2000): History, Memory, and the Historian: Dilemmas and Responsibilities. New German Critique 80, 3-15.

Fukuoka, Kazuya (2011): School History Textbooks and Historical Memories in Japan: A Study of Reception. International Journal of Politics, Culture, and Society 24, 83-103.

Fullard, Katja (2010): Memory and Identity in Autobiographical Texts by Günter Grass and Dieter Wallershoff. Rocky Mountain Review 64 (1): 71-85.

Gagiano, Annie (2004): Adapting the National Imaginary: Shifting Identities in Three Post-1994 South African Novels. Journal of Southern African Studies 30 (4): 811-824.

Gotham, Kevin Fox, Greenberg, Miriam (2008): From 9/11 to 8/29: Post-Disaster Recovery and Rebuilding in New York and New Orleans. Social Forces 87 (2): 1039-1062.

Gregor, Neil (2001): Four Days in April 2000: The 55th Anniversary of the Liberation of Ravensbrück. Journal of Holocaust Education 10 (2): 71-78.

GROSS, Jan Tomasz (2000): Sąsiedzi. Historia zagłady żydowskiego miasteczka. Sejny: Pogranicze. 
Grosswald Curran, Vivian (2003): The Politics of Memory / Errinerungspolitik and the use propriety of law in the process of memory construction. Law and Critique 14, 309-323.

Grundlingh, Albert (2004): Refraining Remembrance:The Politics of Centenary Commemoration of the South African War of 1899-1902. Journal of Southern African Politics 30 (2): 359-375.

Gutwein, Daniel (2009): The Privatization of the Holocaust: Memory, Historiography, and Politics. Israel Studies 14 (1): 36-64.

Guyot, Sylvain, Seethal, Cecil (2007): Identity of Place, Places of Identity, Change of Place Names in Post-Apartheid South Africa. South African Geographical Journal 89 (1): 55-63.

Hjarvard, Stig (2008): The Mediatization of Society. A Theory of Media as Agents of Social and Cultural Change. Nordicom Review 29 (2): 105-134.

Hoerschelmann, Olaf (2001): „Memoria Dextra Est": Film and Public Memory in Postwar Germany. Cinema Journal 40 (2): 78-97.

Jackman, Robert W., Miller, Ross A. (1996): A Renaissance of Political Culture? American Journal of Political Science 40 (3): 632-659.

Kansteiner, Wulf (2004): Nazis, Viewers, and Statistics: Television History, Television Audience Research and Collective Memory in West Germany. Journal of Contemporary History 39 (4): 575-598.

Kattago, Siobhan (2001): Ambiguous Memory. The Nazi Past and German National Identity. Westport - London: Praeger.

Khalili, Laleh (2007): Heroes and Martyrs of Palestine. The Politics of National Commemoration. Oxford - New York: Oxford University Press.

Koczanowicz, Leszek (1997): Memory of Politics and Politics of Memory. Reflections on the Construction of the Past in Post-Totalitarian Poland. Studies in East European Thought 49, 259-270.

Korzeniewski, Bartosz (2007): Teoria kultury a badania nad pamięcią społeczną. Kultura Wspótczesna 2, 6-15.

Korzeniewski, Bartosz (2010): Transformacja Pamięci. Przewartościowania w pamięci przeszłości a wybrane aspekty funkcjonowania dyskursu publicznego w Polsce po 1989 roku. Poznań: Wydawnictwo Poznańskiego Towarzystwa Przyjaciół Nauk.

Krasnodębski, Zdzisław (2008): Rozmowy istotne i nieistotne, in I- Sariusz-Skąpska. Pamięćjako przedmiot władzy. Warszawa: Fundacja im. Stefana Batorego, 17-21.

Król, Marcin (2008): Manipulacje władzy, in I. Sariusz-Skąpska. Pamięć jako przedmiot władzy. Warszawa: Fundacja im. Stefana Batorego, 23-25.

Kuźniar, Roman (2012): Polityka zagraniczna III Rzeczypospolitej. Warszawa: Wydawnictwo Naukowe Scholar.

Landsberg, Alison (1997): America, the Holocaust, and the Mass Culture of Memory: Towards a Radical Politics of Empathy. New German Critique 71, 63-86.

Lijphard, Arend (1999): Patterns of Democracy: Government Forms and Performance in Thirty-Six Countries. New Haven: Yale University Press.

Lisus, Nicola A., Ericson, Richard V. (1995): Misplacing Memory: The Effect of Television Format on Holocaust Remembrance. The British Journal of Sociology 46 (1): 1-19. 
Macginty, Roger (2001): The Political Use of Symbols of Accord and Discord: Northern Ireland and South Africa. Civil Wars 4 (1): 1-21.

Machcewicz, Paweł (2012). Spory o historię 2000-2011. Krakow: Wydawnictwo Znak.

Magierska, Anna (2008): Polityka historyczna - politycy - historia. Społeczeństwo i Polityka 4, 9-27.

Mazzoleni, Gianpietro, Schultz, Winfried (1999): 'Mediatization' of Politics: A Challenge for Democracy? Political Communication 16 (3): 247-261.

Meseth, Wolfgang, Proske, Matthias (2010): Mind the gap: Holocaust Education in Germany, between pedagogical intentions and classroom interactions. Prospects 40, 201-222.

Meyen, Michael, Pfaff-Rüdigen, Senta (2014): Mass Media and Memory: the Communist GDR in Today's Communicative Memory. Medijske Studije - Media Studies 5, 3-18.

Mitter, Rana (2003): Old Ghosts, New Memories: China's Changing War History in the Era of Post-Mao Politics. Journal of Contemporary History 38 (1): 117-131.

Moyn, Samuel (1998): Two Regimes of Memory. The American Historical Review 103 (4): 1182-1186.

Ponczek, Eugeniusz (2007): Kultura polityczna społeczeństwa polskiego. Doświadczenia dziejowe oraz znaki czasu współczesności i przyszłości. Prace Naukowe Akademii im. Jana Długosza w Częstochowie. Res Politicae 2, 117-133.

Rydel, Jan (2011): Polityka historyczna w Republice Federalnej Niemiec. Zaszłości. Idee. Praktyka. Krakow: Wydawnictwo Naukowe Uniwersytetu Pedagogicznego.

Schaller, Dominik J. (2007): From the Editors: genocide tourism - educational value or voyeurism? Journal of Genocide Studies 9 (4): 513-515.

Schramm, Katharina (2011): Introduction. Landscapes of Violence: Memory and Sacred Space. History \& Memory 23: 1, 5-22.

Schwartz, Barry (1996): Memory as Cultural System: Abraham Lincoln in World War II. American Sociological Review 61 (5): 908-927.

Schwartz, Barry, Schuman, Howard (2005): History, Commemoration, and Belief: Abraham Lincoln in American Memory, 1945-2001. American Sociological Review 70 (2): 183-203.

Seo, Jungmin (2008): Politics of Memory in Korea and China: Remembering the Comfort Women and Nanjing Massacre. New Political Science 30 (3): 369-392.

Shafir, Michael (2014): Unacademic academics: Holocaust deniers and trivializes in post-Communist Romania. Nationalities Papers 42 (6): 942-964.

Smith, Rogers (2003): Stories of Peoplehood: The Politics and Mortality of Political Membership. New York: Cambridge University Press.

Smoczyńska, Anna, Górowska-Fells, Magdalena, Maluchnik, Beata, Płatos, Beata, Chojnacki, Michat, Smolik, Marcin (2012): The System of Education in Poland. Warszawa: Polish Eurydice Unit \& Foundation for the Development of the Education System.

Stan, Lavinia (2006): The Vanishing Truth? Politics and Memory in Post-Communist Europe. East European Quarterly 40 (4): 383-408. 
Tamm, Marek (2014): Truth, Objectivity and Evidence in History Writing. Journal of the Philosophy of History 8, 265-290.

Uldricks, Teddy J. (2009): War, Politics and Memory. Russian Historians Reevaluate the Origins of World War II. History \& Memory 21 (2): 60-82.

Valiñas, Marta, Vanspauwen, Kris (2009): Truth-seeking after violent conflict: experiences from South Africa and Bosnia and Herzegovina. Contemporary Justice Review 12 (3): 269-288.

Wang, Zheng (2008): National Humiliation, History Education, and the Politics of Historical Memory: Patriotic Education Campaign in China. International Studies Quarterly 52, 783-806.

Wawrzyński, Patryk (2012): The Usage of Politics of Memory in Polish Foreign Policy: Present State and Perspectives. Copernicus Journal of Political Studies 1, 67-91.

Wawrzyński, Patryk (2014): Sharing the Past: Specialized Institutions as an instrument of Politics of Memory in the $21^{\text {st }}$ Century, in R. Schattkowsky, M. Řeznik. Society and Nation in Transnational Processes in Europe. Newcastle: Cambridge Scholar Publishing, in print.

Wawrzyński, Patryk, Ratke-Majewska, Anna, Marszałek-Kawa, Joanna (2015): The Transformation of National Identity and the Remembrance during Post-Authoritarian Transitions: case studies of Spain and South Africa. Journal of Identity and Migration Studies 9 (1): 19-32.

Westen, Drew (2008): The Political Brain. The role of emotion in deciding the fate of the Nation. New York: Public Affairs.

Withuis, Jolande (2010): Introduction: the Politics of War Trauma, in J. Withuis \& A. Mooij. The Politics of War Trauma. The aftermath of World War II in eleven European countries, Amsterdam: Aksant, 1-11.

Wolff-Powęska, Anna (2007): Polskie spory o historię i pamięć. Polityka historyczna. Przegląd Zachodni 1, 3-44.

Worthy, Scott (2004): Communities of Remembrance: Making Auckland's War Memorial Museum. Journal of Contemporary History 39 (4): 599-618.

Yablonka, Hanna (2009): Izraelczycy i Szoah: pamięć, tożsamość i dyskurs, in E. Kossewska. Brzemię pamięci. Wspótczesne stosunki polsko-izraelskie. Warszawa: Wydawnictwo Neriton, 95-112.

Dr. Patryk Wawrzyński - researcher at the Nicolaus Copernicus University in Torun, Poland, and visiting researcher at the University of Cape Town, South Africa. He develops research in political culture, remembrance policy, politics of memory and transitional studies, mostly in Central Europe and Southern Africa. E-mail: patryk. wawrzynski@gmail.com.

prof. Ralph Schattkowsky - Chair of International Relations' History at the Nicolaus Copernicus University in Toruń, faculty at the University in Rostock, Germany. He develops research in civic society, identity politics and the history of German-Polish relations.E-mail: rascha@umk.pl. 